\title{
IS THE MARKET OVER-OPTIMISTIC ABOUT THE PROSPECTS OF FIRMS THAT ISSUE EQUITY? EVIDENCE FOR THE SPANISH MARKET ${ }^{*}$
}

\author{
María J. Pastor-Llorca and J. Carlos Gómez-Sala**
}

WP-EC 2004-06

Corresponding author: María J. Pastor-Llorca: Dpto. Economía Financiera, Contabilidad y Marketing, Universidad de Alicante, Apdo. Correos 99, 03080 ALICANTE, SPAIN, Tf./Fax: +34 965-90-36-21, e-mail: maria.pastor@ua.es.

Editor: Instituto Valenciano de Investigaciones Económicas, S.A.

Primera Edición Febrero 2004.

Depósito Legal: V-1052-2004

IVIE working papers offer in advance the results of economic research under way in order to encourage a discussion process before sending them to scientific journals for their final publication.

\footnotetext{
* We acknowledge financial support from Ministerio de Ciencia y Tecnología (MCYT) with the project BEC2002-03797.

** M.J. Pastor-Llorca and J.C. Gómez-Sala: Dpto. Economía Financiera, Contabilidad y Marketing, Universidad de Alicante.
} 


\title{
IS THE MARKET OVER-OPTIMISTIC ABOUT THE PROSPECTS OF FIRMS THAT ISSUE EQUITY? EVIDENCE FOR THE SPANISH MARKET
}

\author{
Ma Jesús Pastor-Llorca and J. Carlos Gómez-Sala
}

\begin{abstract}
Previous evidence has documented that equity issuers underperform in the long-run. One possible explanation is that investors have overoptimistic expectations regarding future earnings and the underperformance occurs as these expectations are corrected over time. Our central focus is to test this hypothesis for Spanish rights issuing firms, for that, firstly we examine analysts' predictions about future earnings of these companies. We observe that forecasts are unusually favourable and, moreover, the post-offering underperformance is most pronounced when analyst predictions have higher optimistic bias. Secondly, we study the market response to issuing firms' earnings announcements in the post-offering period observing a significant negative reaction. So the evidence in this paper is consistent with the excessive optimism hypothesis about issuing firms.
\end{abstract}

Keywords: Corporate Finance, Seasoned Equity Offerings, Earnings Forecasting.

JEL classification: G14, G32.

\section{RESUMEN}

Evidencia previa ha documentado que las empresas que amplían capital experimentan rentabilidades anormales negativas en el largo plazo. Una posible explicación es que los inversores tienen expectativas excesivamente optimistas sobre los beneficios futuros de estas compañías y la evolución observada se debe a la corrección gradual de este exceso de optimismo. El principal objeto de este trabajo es contrastar esta hipótesis para las emisiones con derechos en el mercado español. Para ello, en primer lugar se examinan los pronósticos de los analistas sobre los beneficios futuros de las empresas emisoras. Se observa que las predicciones para estas compañías son inusualmente favorables y, además, la peor evolución a largo plazo es más pronunciada cuando las predicciones son más optimistas. En segundo lugar, se estudia la reacción del mercado a los anuncios de beneficios de las compañías emisoras los años siguientes a la oferta, observando una reacción significativamente negativa. Por tanto, la evidencia aportada en este trabajo es consistente con la hipótesis de expectativas excesivamente optimistas sobre las empresas que deciden ampliar capital.

Palabras claves: Finanzas corporativas, ampliaciones de capital, predicciones de beneficios. 


\section{Introduction}

One of the puzzles of the modern financial literature is the negative long-run abnormal returns following equity issues. In an efficient capital market the information provided by this event should be reflected in stock prices in the announcement and no abnormal performance should appear afterwards. However, extant studies have documented negative long-run abnormal returns up to five years after equity offerings. Loughran and Ritter $(1995,1997)$, Spiess and Affleck-Graves (1995), Lee (1997) and Jegadeesh (2000) document this anomaly for firm commitments offerings in the US market. The evidence for rights issues also show long-run post-issue underperformance: Cai (1998) and Kang, Kim and Stulz (1999) in Japan; Jeanneret (2000) in the French market; Stehle, Ehrhardt and Przyborowsky (2000) in Germany; and Pastor and Martín (2001, 2004) in Spain.

The interpretation of the above pattern has been the subject of considerable debate. On one hand, several authors document important biases in measuring and testing returns in large periods, thus the long-run abnormal returns could be explained by these biases (Barber and Lyon, 1997; Kothari and Warner, 1997; Lyon, Barber and Tsay, 1999). However, recent studies have included substantial improvements in the methodology employed in order to minimise the influence of these biases and their results continue showing long-run underperformance of issuing firms in relation to non-issuers. On the other hand, some authors suggest that it is the correction of investors' optimistic expectations of future performance that causes the long-run underperformance in stock returns (Loughran and Ritter, 1997; Kang, Kim and Stulz, 1999; Jegadeesh, 2000).

Several studies have tried to test this optimistic expectations hypothesis. As the market expectations are not observable, some authors examine the optimism reflected in analysts' earnings forecasts to provide indirect evidence regarding the market optimism. In this context, Ali (1996) and Teoh and Wong (2002) document that one-year analysts' earnings forecasts for issuing firms have higher optimistic bias than for non-issuers in the period of five years following the offering. However, Hansen and Sarin (1998) document that one-year earnings prediction for equity issuers around the offering are not more favourable than for non-issuing firms. The results in relation to long-term growth forecast around equity issues are not conclusive either. Hansen and Sarin (1998) reject that long-run growth forecasts are more favourable for issuing firms, but the results obtained by Dechow, Hutton and Sloan (2000) are 
consistent with the existence of an overly optimistic bias in long-run growth prospects around equity offerings.

Another trend of investigation examines investors' reaction to post-issue earnings announcements as a direct test of the optimistic expectations hypothesis. Cornett, Mehran and Tehranian (1998) study post-issue performance for a sample of publicly traded commercial banks. They find that voluntary issue equity exhibit post-offering long-run underperformance and, moreover, these firms experience a negative market reaction to quarterly earning announcements following the issue. Rangan (1998), Jegadeesh (2000) and Denis and Sarin (2001) also examine abnormal returns around earnings announcement following the offering and they report that earnings announcement are associate with significantly negative abnormal returns. However, the evidence in Shivakumar (2000) and Brous, Datar and Kini (2001) suggests that investors are not disappointed by earnings announcements that follow seasoned equity offerings.

On one hand, this paper extends previous literature analysing for the first time the existence of overoptimistic expectations for rights offerings. Although there is evidence of long-run stock price underperformance following equity issues with rights, all extant studies trying to test the overoptimistic hypothesis has focused on firm commitments offerings. A priori, what we would expect is that in rights issues the level of optimism in expectations was lower, in relation to firm commitments, given that in rights offerings potential purchasers for new shares are basically current shareholders.

On the other hand, given that the evidence about the optimistic expectations hypothesis for firm commitments is mixed, we try in our study to improve methodology and to use different procedures to test this hypothesis in order to clarify if the excessive optimism can explain the equity issue puzzle. In particular, we introduce a multivariate regression analysis using data panel that complement the usual descriptive univariate analysis applied in this context.

Firstly we examine analysts' errors in their prospects of future earnings. We observe that analysts' earnings forecasts for rights issuers are unusually favourable and, moreover, the poor long-run performance is more pronounced for issuing firms with more optimistic predictions. Secondly, we focus on post-issue earnings announcement effects observing a negative reaction to earning announcements the years following the offering. Thus, the 
evidence in this paper is consistent with the existence of excessive optimism about rights issuing firms' future earnings.

The paper proceeds as follows. Section 2 describes the sample selection procedure and data sources. Section 3 examines the long-term stock-price performance of Spanish rights issues. In section 4 we study analysts' forecast errors in their predictions about future earnings of issuing firms and the explicative power of these errors in long-run returns. Section 5 analyses the market reaction to post-offering earning announcements. Finally, conclusions are presented.

\section{Sample and data sources}

To identify firms issuing equity, we use the Comisión Nacional del Mercado de Valores (C.N.M.V.) ${ }^{1}$ register. During the period from April 1989 to December 1996, 125 rights offerings of listed firms are located.

To isolate the effect of long-run equity issues, we exclude firms that are the object of any decision or special situation in the three-year post-issue period, which may affect results. Specifically, we remove firms that issue convertible bonds, are involved in any merger, acquisition or takeover processes in this period, suffer a stoppage of payments, or are preventively or definitively excluded in listing. Additionally, in order to avoid cross-section dependence, if an issue of a firm is included in the final sample, no other issue of the same firm in the three-year post-issue period is included. Furthermore, to compute long-run abnormal returns we need size and book-to-market data of issuing firms at the end of the year prior to the offering. This leaves us with 44 rights offerings in our sample.

In table 1 size and book-to-market ratios of issuing firms are compared with the values of these variables for the market. ${ }^{2} \mathrm{We}$ observe that issuing firms are statistically significantly smaller and they are high growth firms.

\footnotetext{
${ }^{1}$ This Spanish institution is the equivalent of the American S.E.C.

${ }^{2}$ To determine values for the market, we have employed all the firms with size and book-to-market values available in December of the year prior to the offering.
} 
TABLE 1. SUMMARY STATISTICS FOR FIRM CHARACTERISTICS OF EQUITY RIGHTS ISSUES

\begin{tabular}{llccccc}
\hline & & Mean & Median & Maximum & Minimum & Std. Dev. \\
\hline Issuing & $\begin{array}{l}\text { Firm size } \\
\text { Firms }\end{array}$ & 277.17 & 141.05 & 1592.35 & 15.60 & 317.81 \\
& BTM $^{2}$ & 1.08 & 0.80 & 3.65 & 0.19 & 0.81 \\
\multirow{2}{*}{ Market } & $\begin{array}{l}\text { Firm size } \\
(\text { millions of } €)^{1}\end{array}$ & 569.37 & 519.64 & 845.72 & 435.59 & 134.11 \\
& BTM $^{2}$ & 1.36 & 1.29 & 2.41 & 0.76 & 0.60 \\
\hline
\end{tabular}

${ }^{1}$ The firm size at month $t$ is measured as its number of stocks in December of the previous year multiplied by the stock price at the end of the previous month.

${ }^{2}$ BTM is the book to market ratio, measured at month $t$ as the book value of common stock in December of the previous year relative to the firm size at the end of the previous month.

To measure long-run stock price performance, monthly returns adjusted by dividends, rights issues and splits are employed. This information comes from the Spanish Stock Exchange (SSE). We also need information from the Institutional Brokers Estimation System (IBES) database about analysts' predictions of issuing firms' future earnings. In particular, we used the following forecasts: (i) one-year earning forecasts made by analysts the year previous to the offering, the year of the offering and in each of the three years following the issue; (ii) two-year earning predictions made by analysts the year previous to the offering, the year of the offering and the following one (iii) three-year earning forecasts made by analysts the year previous to the offering, the year of the offering and the following one.

Analysts' prediction data for the 44 companies are not available for all the selected dates, so the analysis is carried out for the companies with analysts' prediction data available. To measure forecast errors we compare the mean analysts' forecast with the actual earning that is also available in IBES database. In order to test if analysts' predictions for issuing firms are unusually favourable, we compare the forecast error for each issuing firm with forecast 
errors in the same dates for non-issuer control firms ${ }^{3}$. Predictions and earnings data for control firms are also obtained from IBES database.

For the analysis of the post-issue earnings announcement effects, we collect the four annual earning announcement dates subsequent to the issue from JCF Quant file. ${ }^{4}$ In particular, the announcement of the issue-year earning (which is published at the beginning of the following year) and the three subsequent annual earning announcements. We extract daily issuing firms' returns from the Spanish Stock Exchange (SSE).

\section{Long-Run performance of post-issue stock returns}

In this section we study the long-run market reaction to equity rights issues. For that, we calculate the abnormal return in the analysis period, $A C o R_{i, \tau}$, as the compound return of the issuing firm minus the compound expected return:

$$
A \operatorname{CoR}_{i, \tau}=\prod_{t=1}^{\tau}\left(1+R_{i, t}\right)-\prod_{t=1}^{\tau}\left(1+E\left(R_{i, t}\right)\right)
$$

Given that the empirical evidence has demonstrated that the size and book to market ratio (BTM) explain the cross-section variability of stocks returns, to estimate expected returns we select reference portfolios on the basis of these control variables. Firstly, we select for each issuing firm, with an event date, its non-issuers group. The non-issuers group is composed of firms that do not issue equity either in the three-year period previous to the event date or in the three-year period following it. For each issuing, non-issuer companies are grouped in size quartiles, BTM quartiles or size-and-BTM quartiles at the end of the pre-issue year. The expected return is the return of the issue firm quartile.

\footnotetext{
${ }^{3}$ Analysts made their predictions about the earning for a given year each month until the earning announcement. Companies announce their results in the six-month period following the end of the year, although the exact date differs for each firm. It is expected that with the passage of time forecasts become more accurate, thus to compare forecast error for issuers and non-issuers we have to analyse predictions in the same month for both groups. We choose December as the month in which we study forecasts errors for issuers and non-issuers. However, for the year of the offering we analyse the predictions in the month previous to the announcement and in the following one in order to detect possible changes in analysts' forecast due to the offering announcement.

4 Earning announcement data started in 1991 so we do not have the four earning announcements dates for all issuing firm. The analysis will be carried out in each date with the data available.
} 
In order to test the statistical significance of the abnormal returns, we first compute $t$ statistics for the different normal return estimation procedures. Moreover, as the distribution of long-run abnormal returns is positively skewed when reference portfolios are employed to estimate normal returns, we also calculate the skewness-adjusted $t$ statistic ${ }^{5}$.

$$
t_{\text {skewness-adjusted }}=\sqrt{N}\left(S+\frac{1}{3} \hat{\gamma} S^{2}+\frac{1}{6 N} \hat{\gamma}\right)
$$

where $N$ is the number of events in the sample; $S=A A C o R_{\tau} / \sigma(A C o R \tau) ; \hat{\gamma}$ is the coefficient of skewness, estimated as $\sum_{i=1}^{N}\left(A C o R_{i, \tau}-A A C o R_{\tau}\right)^{3} / N \sigma\left(A C o R_{\tau}\right)^{3}$; and $A A C o R_{\tau}$ and $\sigma\left(A C o R_{\tau}\right)$ are the sample mean and cross-sectional standard deviation of abnormal returns for the sample of $N$ events.

Table 2 reports abnormal returns computed using different benchmarks to estimate expected returns for different intervals following the issue, as well as the results of the statistical tests. We observe that issuing firms under-perform their benchmarks in the three years post-issue period; moreover, results are highly significant whatever the benchmark employed.

TABLE 2. STOCK RETURN LONG-RUN PERFORMANCE FOLLOWING THE ISSUE

\begin{tabular}{|c|c|c|c|c|}
\hline Year after the SEO & & +1 & +2 & +3 \\
\hline Size portfolio & $\begin{array}{l}\text { AACoR ( \%) } \\
\text { t stat. } \\
\text { t skewness-adjust. }\end{array}$ & $\begin{array}{l}-8.19 \\
-1.86^{*} \\
-1.78^{*}\end{array}$ & $\begin{array}{c}-23.77 \\
-3.90^{* * *} \\
-3.39^{* * *}\end{array}$ & $\begin{array}{l}-35.27 \\
-3.05^{* * *} \\
-2.26^{* *}\end{array}$ \\
\hline BTM portfolio & $\begin{array}{l}\text { AACoR ( \%) } \\
\text { t stat. } \\
\text { t skewness-adjust. }\end{array}$ & $\begin{array}{c}-8.33 \\
-2.06^{* *} \\
-1.97 * *\end{array}$ & $\begin{array}{c}-22.22 \\
-3.63^{* * *} \\
-2.95^{* * *}\end{array}$ & $\begin{array}{l}-26.26 \\
-2.25^{* *} \\
-1.75^{*}\end{array}$ \\
\hline Size-BTM portfolio & $\begin{array}{l}\text { AACoR ( \%) } \\
\text { t stat. } \\
\text { t skewness-adjust. }\end{array}$ & $\begin{array}{l}-6.63 \\
-1.58 \\
-1.56\end{array}$ & $\begin{array}{c}-20.55 \\
-3.56 * * * \\
-3.03^{* * *}\end{array}$ & $\begin{array}{l}-26.38 \\
-2.42 * * \\
-1.84^{*}\end{array}$ \\
\hline
\end{tabular}

$*, * *$ and $* * *$ denote significance at $10 \%, 5 \%$ and $1 \%$ levels, respectively.

${ }^{5}$ Lyon, Barber and Tsai (1999) advocate the use of this statistic originally developed by Johnson (1978). 


\section{Analysts' forecasting errors around the offering}

The focus of this part of the paper is to test the optimistic expectations hypothesis about rights issues examining analysts' predictions about future earnings for these companies. If forecasts for issuing firms are unusually favourable this would support this hypothesis. In this context, it is important to notice that previous evidence documents that analysts' prospects are, in mean, optimistically biased. ${ }^{6}$ Thus, our interest is to analyse if the optimistic bias in analysts' forecast about issuing firms is higher than the bias usually made by analysts in their predictions. In particular, we analyse if in the years around the offering there is a significant difference between the forecast errors for issuers and non-issuers.

\subsection{Univariate tests}

The forecast error results from the difference between the actual and forecasted earning per share. Obviously, to make this magnitude of the forecast error comparable between firms a deflator must be used. However, previous literature lacks a consensus regarding the use of the deflator. The commonly used deflator is the stock price (Brous, 1992; Ali, 1996; Rajan and Servaes, 1997; Hansen and Sarin, 1998; Richardson, Teoh and Wysocki, 2001; Doukas, Kim and Pantzalis, 2001; Teoh and Wong, 2002; Marciukaityte and Szewczyk, 2001). The rationale to choose the stock price deflator rather than the earning per share is to improve the statistical properties of the errors predictions series and then, the reliability of the test. ${ }^{7}$

However, Mian and Teo (2001) argue that if stocks have different earnings-to-price ratios, cross-sectional comparisons of forecast errors using stock price deflator may lead to spurious results. For example, suppose two stocks A and B with different prices, $2 €$ and $1 €$, respectively but with the same earning per share prediction of 0.02 . Imagine that the actual earning per share of both stocks turn out to be half than of what were anticipated, 0.01 . If we use the stock price as the deflator, the forecast error in absolute value would be 0.005 for stock A and 0.01 for stock B, when for both stocks the error made by analysts is the same.

\footnotetext{
6 Elton, Gruber and Gultein (1984); Brown, Foster and Noreen (1985); O’Brien (1988); Dreman and Berry (1995); McNichols and O’Brien (1997); Brown (1996, 1997); Hansen and Sarin (1998); Larrán and Rees (1999); Dechow, Hutton and Sloan (2000).

${ }^{7}$ Using the actual or forecasted earning as deflator implies the possibility of having in the denominator a number closely to zero or zero. In this context, Dreman and Berry (1995) document that a big number of outliers arise when the earning or the prediction are used as deflator.
} 
This example serves to illustrate that using stock price deflator implies more weight for forecast errors of stocks with low prices relative to actual or forecasted earnings. Therefore, firms with higher actual or forecasted earning in relation to price presents an upward bias in absolute value forecast errors. ${ }^{8}$ This bias in the cross-sectional comparison of forecast errors for firms with different earning-to-price ratio if the forecast errors are deflated by stock prices, leads Mian and Teo (2001) to defend the absolute value of actual or forecasted earning per share as deflators, in spite of the statistical problems previously commented.

We analyse if, as Mian and Teo (2001) argue, firms with higher actual or forecasted earning in relation to price present upward bias in forecast errors when stock price is used as deflator. We compute, for every firm in IBES database, forecast errors deflated by stock price in December of each year in the sample period. We observe that forecast errors in absolute value present a significant positive correlation with the actual and forecasted earning to price ratio. This correlation is not significant when errors are deflated by the absolute value of forecasted earning (see Appendix).

These results are similar to those obtained by Hansen and Sarin (1998) and agree with the argument of Mian and Teo (2001). Thus, if we use stock price deflator differences in forecast errors between issuers and non-issuers could arise if they have different earning-toprice ratios. In this context, firstly we compute forecast errors scaled by stock prices given the better statistical properties; but, to avoid the problems that could arise in cross-sectional comparisons of forecast errors if firms have different earning-to-price ratio, we compare the forecast errors deflated by price of issuing firms with errors for non-issuers with similar ratio. In particular, for each issuing firm, non-issuer companies are grouped in quartiles on the basis on the forecasted earning-to-price ratio and we compare the error for each issuing firm with the error for its non-issuers quartile. Secondly, we compute forecast errors using the absolute value of forecasted earning as deflator, as Mian and Teo (2001) defend. In this case the control group for each issuing firm is its non-issuers group.

\footnotetext{
${ }^{8}$ Hansen and Sarin (1998), using stock price as the deflator forecast error, document that optimistic bias in analysts' predictions is higher for companies with higher forecasted earning-to-price ratios. However, this result could be due to the spurious relationship between earning-to-price ratios and forecasted errors deflated by stock prices. Other studies that could be possibly affected by this bias are those that, using stock price deflator, document that firms with higher book to market ratios have higher forecast errors in absolute value (Richardson, Teoh and Wysocki, 2000; Doukas, Kim and Pantzalis, 2001). These results could be due to the positive correlation between book-to-market and earning-to-price ratios. Mian and Teo (2001) document no significant relation between book-to-market ratio and forecast errors deflated by earning.
} 
To test if the mean forecast error for issuing firms is equal to the mean error for nonissuers we employ a bootstrap procedure because we consider restrictive to suppose a distribution of forecast errors. ${ }^{9}$ With the bootstrap technique we generate the forecast errors empirical distribution for the non-issuers control group and we employ this distribution to evaluate the statistical significance of the issuing firm mean forecast error. Specifically, for each issuing firm, we randomly select, with replacement, a firm that is in its control group. Repeating this process for all issuing firms we obtain one pseudo-portfolio with firms randomly selected that have not issued. Then, we compute the mean forecast error of this pseudo-portfolio. This process is repeated 10,000 times to obtain the empirical distribution of non-issuing mean forecast error. This distribution is used to fix the percentiles to test equality between issuing and the pseudo-portfolio mean forecast error.

Panel A of table 3 show the results for short-term predictions. Specifically, we analyse on-year predictions made by analysts the year prior to the issue, the year of the offering and in the three years following the issue. We observe that one-year earning predictions for issuing firms in every selected date are in mean optimistic, that is, the mean analysts' prediction is higher than the actual earning. Furthermore, forecast errors are higher the years following the offering. Similar evidence is documented by Hansen and Sarin (1998) and Marciukaityte and Szewczyk (2001), and is consistent with the argument that in the years following the offering the good expectations about issuing firms' earnings are not confirmed.

Comparing forecasting errors for issuers and non-issuers we observe that in the year previous to the offering the mean forecast error made by analysts for issuing firms is not significantly different from the prediction error for non-issuers. However, in the year of the offering and in each of the following three years, forecast errors are significantly more negative for issuing firms sample. Moreover, results are robust to the deflator employed.

Thus, the evidence here shows that the optimistic bias in expectations about postoffering earnings is significantly higher. Additionally, this excessive optimism does not disappear immediately, it continues in the three-year period following the offering. These results are consistent with Ali (1996) and Teoh and Wong (2002).

\footnotetext{
${ }^{9}$ With the Jarque-Bera test the normality of the forecast errors distribution is rejected.
} 
TABLE 3. ANALYSTS' FORECASTING ERRORS AROUND THE OFFERING

\begin{tabular}{|c|c|c|c|c|c|c|c|c|c|c|c|c|}
\hline \multirow[b]{2}{*}{$\begin{array}{l}\text { Prediction } \\
\text { date }\end{array}$} & \multicolumn{6}{|c|}{ Price Deflated Error $^{1}(\%)$} & \multicolumn{6}{|c|}{ Forecast Deflated Error ${ }^{2}(\%)$} \\
\hline & $\begin{array}{c}\text { year } \\
-1 \\
\end{array}$ & $\begin{array}{c}\text { month } \\
\text { pre. }\end{array}$ & $\begin{array}{l}\text { month } \\
\text { post. }\end{array}$ & $\begin{array}{c}\text { Year } \\
+1 \\
\end{array}$ & $\begin{array}{c}\text { year } \\
+2 \\
\end{array}$ & $\begin{array}{c}\text { year } \\
+3 \\
\end{array}$ & $\begin{array}{c}\text { year } \\
-1 \\
\end{array}$ & $\begin{array}{c}\text { month } \\
\text { pre. }\end{array}$ & $\begin{array}{c}\text { month } \\
\text { post. }\end{array}$ & $\begin{array}{c}\text { year } \\
+1 \\
\end{array}$ & $\begin{array}{c}\text { year } \\
+2\end{array}$ & $\begin{array}{c}\text { year } \\
+3 \\
\end{array}$ \\
\hline \multicolumn{13}{|c|}{ Panel A. One-Year Predictions } \\
\hline Issuers & -2.33 & -1.67 & -2.39 & -4.92 & -4.62 & -11.96 & -11.12 & -15.66 & -33.99 & -82.70 & -76.48 & -119.6 \\
\hline Non-Issuers & -0.69 & 0.16 & 0.12 & -0.47 & -1.05 & -0.87 & -3.17 & 2.55 & -0.21 & -1.92 & -4.49 & -0.82 \\
\hline $\begin{array}{l}\text { Bootstrap } \\
\text { p-value }\end{array}$ & $(0.17)$ & $(0.00)$ & $(0.00)$ & $(0.00)$ & $(0.00)$ & $(0.00)$ & $(0.19)$ & $(0.00)$ & $(0.00)$ & $(0.00)$ & $(0.00)$ & $(0.00)$ \\
\hline \# of firms & 33 & 34 & 34 & 33 & 37 & 36 & 33 & 34 & 34 & 33 & 37 & 36 \\
\hline \multicolumn{13}{|c|}{ Panel B. Two-Year Predictions } \\
\hline Issuers & -4.22 & -4.18 & -5.42 & -3.72 & & & -26.71 & -53.63 & -58.89 & -58.09 & & \\
\hline Non-Issuers & -0.81 & -0.52 & 0.05 & -0.67 & & & -4.30 & 0.31 & 5.09 & 4.39 & & \\
\hline $\begin{array}{l}\text { Bootstrap } \\
\text { p-value }\end{array}$ & $(0.00)$ & $(0.00)$ & $(0.00)$ & $(0.00)$ & & & $(0.05)$ & $(0.00)$ & $(0.00)$ & $(0.00)$ & & \\
\hline \# of firms & 31 & 33 & 33 & 35 & & & 31 & 33 & 33 & 35 & & \\
\hline \multicolumn{13}{|c|}{ Panel C. Three-Year Predictions } \\
\hline Issuers & -5.46 & -7.46 & -6.34 & -5.55 & & & -30.87 & -73.59 & -77.09 & -81.25 & & \\
\hline Non-Issuers & -0.94 & -0.44 & -1.20 & -1.30 & & & -7.89 & -4.21 & -12.23 & -8.58 & & \\
\hline $\begin{array}{l}\text { Bootstrap } \\
\text { p-value }\end{array}$ & $(0.00)$ & $(0.00)$ & $(0.00)$ & $(0.01)$ & & & $(0.02)$ & $(0.00)$ & $(0.00)$ & $(0.01)$ & & \\
\hline \# of firms & 25 & 34 & 34 & 30 & & & 25 & 34 & 34 & 30 & & \\
\hline
\end{tabular}

${ }^{1}$ Price deflated error is computed as the actual earning per share minus the mean forecasted earning per share divided by the stock price the month in which the prediction is made. Thus, a negative forecast error implies optimistic bias.

${ }^{2}$ Forecast deflated error is computed as the actual earning per share minus the mean forecasted earning per share divided by the absolute value of the forecasted earning. Thus, a negative forecast error implies optimistic bias.

Several authors suggest that the use of one-year earning forecasts as a measure of expectations could be limited because the issuing firms' poor performance continues several years after the offering. Thus the use of long-term forecast could be more appropriate to test the overly optimistic expectation hypothesis (Hansen and Sarin, 1998; Dechow, Hutton and Sloan, 2000). In this context, these authors employ five-year growth earning forecasts available in IBES database. However, for our sample of issuing firms there are very few fiveyear growth earning forecasts available. Furthermore, as the evidence in the Spanish stock market is that equity issuers underperform from one to three years following the offering, we consider appropriate to use as long-term predictions two- and three-year earning forecasts. Concretely, we analyse two- and three-year earning predictions made by analysts the year before the offering, the year of the issue and the following one. 
Panels B and C of table 3 show that long-term predictions about issuing firms' earnings are, as well as short-term prediction, optimistically biased. That is, the two- and three-year forecast made by analysts are in mean higher than the actual earning for every selected date. Comparing forecast errors for issuing firms with analysts forecasting errors for non-issuers control groups, we observe that for every selected date the error made by analysts in their twoand three- year predictions about issuing firms' earnings is significantly more negative than the error for non-issuers. In sum, results show that analysts are overly optimistic about postoffering issuing firms' earnings.

Clayman and Schwartz (1994), Dowen (1996), Bulter and Saraoglu (1999), Mian and Teo (2001) document that the optimistic bias in forecast errors is higher when the actual earning is negative ${ }^{10}$. We analyse forecast errors in the sample period and we observe that firms with negative actual earnings have significantly more optimistic bias (more negative forecast errors) both if price or forecasted earning is used as deflator. In order to check to what extent results in table 3 are affected by the higher optimistic bias of companies with negative earnings, we repeat the analysis exclusively for the firms with positive earnings ${ }^{11}$. Table 4 shows that the sample of issuing firms with positive earnings presents an optimistic bias, lower than the bias for the global sample, consistent with the argument that optimistic bias in analysts' predictions is more pronounced for firms with negative earnings.

Comparing one-year forecast errors for issuing companies with positive earnings with the error for their non-issuers control groups, we observe that in the year previous to the offering there is no significant difference. In relation to the forecasts made the year of the offering and the following one, the optimistic bias for issuing companies is significantly higher than the bias for non-issuers. However, for the second and third year following the issue prediction errors for equity issuers with positive earning are not significantly different from the error for non-issuers. Thus, the high optimistic bias observed in these years when we analyse the global sample seems to be due to the proportion of companies with losses following the offering.

\footnotetext{
${ }^{10}$ Analysts are reluctant to publish negative earning forecasts, they usually made positive earning prospects even when the actual earning is negative. Moreover, even if predictions are negative they are usually overly optimistic.

${ }^{11}$ Repeating the analysis for issuing firms with positive earning can give us an idea of to what extent results for the global sample are affected by firms with losses. We do not consider appropriate to repeat the analysis exclusively for firms with negative earning due to the small sample size (the number of companies with losses ranges between 3 and 8 depending on the prediction date).
} 
TABLE 4. ANALYSTS' ERRORS AROUND THE OFFERING FOR FIRMS WITH POSITIVE EARNINGS

\begin{tabular}{|c|c|c|c|c|c|c|c|c|c|c|c|c|}
\hline \multirow[b]{2}{*}{$\begin{array}{l}\text { Prediction } \\
\text { date }\end{array}$} & \multicolumn{6}{|c|}{ Price Deflated Error $^{1}(\%)$} & \multicolumn{6}{|c|}{ Forecast Deflated Error ${ }^{2}(\%)$} \\
\hline & $\begin{array}{c}\text { year } \\
-1 \\
\end{array}$ & $\begin{array}{l}\text { month } \\
\text { pre. }\end{array}$ & $\begin{array}{c}\text { month } \\
\text { post. }\end{array}$ & $\begin{array}{c}\text { year } \\
+1 \\
\end{array}$ & $\begin{array}{l}\text { year } \\
+2 \\
\end{array}$ & $\begin{array}{c}\text { year } \\
+3 \\
\end{array}$ & $\begin{array}{c}\text { year } \\
-1 \\
\end{array}$ & $\begin{array}{c}\text { month } \\
\text { pre. }\end{array}$ & $\begin{array}{l}\text { month } \\
\text { post. }\end{array}$ & $\begin{array}{c}\text { year } \\
+1 \\
\end{array}$ & $\begin{array}{c}\text { year } \\
+2 \\
\end{array}$ & $\begin{array}{c}\text { year } \\
+3 \\
\end{array}$ \\
\hline \multicolumn{13}{|c|}{ Panel A. One-Year Predictions } \\
\hline $\begin{array}{l}\text { Issuers } \\
\text { Non-Issuers } \\
\text { Bootstrap } \\
\text { p-value }\end{array}$ & $\begin{array}{l}-1.08 \\
-0.33 \\
(0.13)\end{array}$ & $\begin{array}{c}-1.29 \\
0.01 \\
(0.00)\end{array}$ & $\begin{array}{c}-1.39 \\
-0.12 \\
(0.00)\end{array}$ & $\begin{array}{c}-1.57 \\
0.11 \\
(0.00)\end{array}$ & $\begin{array}{l}-0.63 \\
-0.26 \\
(0.18)\end{array}$ & $\begin{array}{l}-0.19 \\
-0.59 \\
(0.82)\end{array}$ & $\begin{array}{l}-12.59 \\
-3.66 \\
(0.19)\end{array}$ & $\begin{array}{c}-10.35 \\
1.71 \\
(0.04)\end{array}$ & $\begin{array}{c}-13.58 \\
-0.40 \\
(0.01)\end{array}$ & $\begin{array}{l}-31.84 \\
-0.42 \\
(0.00)\end{array}$ & $\begin{array}{l}-4.29 \\
-2.57 \\
(0.75)\end{array}$ & $\begin{array}{c}0.19 \\
3.89 \\
(0.79)\end{array}$ \\
\hline \multicolumn{13}{|c|}{ Panel B. Two-Year Predictions } \\
\hline $\begin{array}{l}\text { Issuers } \\
\text { Non-Issuers } \\
\text { Bootstrap } \\
\text { p-value } \\
\text { \# of firms }\end{array}$ & $\begin{array}{l}-2.11 \\
-0.57 \\
(0.14)\end{array}$ & $\begin{array}{l}-2.79 \\
-0.30 \\
(0.01)\end{array}$ & $\begin{array}{c}-1.64 \\
0.53 \\
(0.01)\end{array}$ & $\begin{array}{c}-1.23 \\
0.14 \\
(0.01)\end{array}$ & & & $\begin{array}{l}-19.53 \\
-3.32 \\
(0.17)\end{array}$ & $\begin{array}{c}-23.06 \\
0.90 \\
(0.03)\end{array}$ & $\begin{array}{c}-19.47 \\
4.89 \\
(0.03)\end{array}$ & $\begin{array}{c}-17.33 \\
-7.28 \\
(0.08) \\
\\
28\end{array}$ & & \\
\hline \multicolumn{13}{|c|}{ Panel C. Three-Year Predictions } \\
\hline $\begin{array}{l}\text { Issuers } \\
\text { Non-Issuers } \\
\text { Bootstrap } \\
\text { p-value } \\
\text { \# of firms }\end{array}$ & $\begin{array}{l}-1.01 \\
-0.70 \\
(0.72)\end{array}$ & $\begin{array}{l}-1.94 \\
-0.10 \\
(0.02)\end{array}$ & $\begin{array}{c}-1.88 \\
-0.49 \\
(0.03)\end{array}$ & $\begin{array}{c}-1.43 \\
0.41 \\
(0.01)\end{array}$ & & & $\begin{array}{l}-17.21 \\
-12.84 \\
(0.63)\end{array}$ & $\begin{array}{c}-21.02 \\
-1.56 \\
(0.10)\end{array}$ & $\begin{array}{l}-18.30 \\
-6.92 \\
(0.18)\end{array}$ & $\begin{array}{c}-15.40 \\
-4.86 \\
(0.13) \\
\\
24\end{array}$ & & \\
\hline
\end{tabular}

${ }^{1}$ Price deflated error is computed as the actual earning per share minus the mean forecasted earning per share divided by the stock price the month in which the prediction is made. Thus, a negative forecast error implies optimistic bias.

${ }^{2}$ Forecast deflated error is computed as the actual earning per share minus the mean forecasted earning per share divided by the absolute value of the forecasted earning. Thus, a negative forecast error implies optimistic bias.

In panel B of table 4, two-year prediction errors for issuing firms with positive earnings are compared with forecast errors for control groups. For predictions made the year prior to the offering the difference is not significant however, two-year forecasts made the year of the offering and the following one present an optimistic bias significantly higher for issuers than for non-issuers. Panel B of table 5 reports three-year forecast errors for offering firms with positive earning and the error for control groups. The year prior to the offering the difference is not significant. In relation to three-year predictions made the year of the offering and the following one, the optimistic bias is larger for issuing companies, although the difference is not statistically significant when the error is scaled by the absolute value of forecasted earning. In general, analysts' predictions for issuer firms are more optimistic than for non-issuers, even after controlling for the higher optimistic bias of companies with negative earnings. 


\subsection{Multivariate analysis}

The tests presented thus far are univariate tests. To better isolate the effect of the equity issue in forecast errors, in this section we run multivariate regressions with a pooled sample of information from both issuing and non-issuing companies. We estimate cross-sectional time series regressions of forecast errors using the following model with company fixed effects,

$$
\begin{aligned}
& F E_{i, t}=\eta_{i}+\beta_{1 I} Y 0_{i, t} \times I_{i, t}+\beta_{2 I} Y 1_{i, t} \times I_{i, t}+\beta_{3 I} Y 2_{i, t} \times I_{i, t}+\beta_{4 I} Y 3_{i, t} \times I_{i, t}+ \\
& +\beta_{1 N I} Y 0_{i, t} \times N I_{i, t}+\beta_{2 N I} Y 1_{i, t} \times N I_{i, t}+\beta_{3 N I} Y 2_{i, t} \times N I_{i, t}+\beta_{4 N I} Y 3_{i, t} \times N I_{i, t}+\varepsilon_{i, t}
\end{aligned}
$$

where $F E_{i, t}$ is the mean one-year forecast error for company $i$ in year $t$, and where $t$ goes from the year previous to the offering to the third year following it. Since in this analysis we compare forecast errors not only between issuers and non-issuers but also over time, we do not consider appropriate to scale prediction errors by price, given that fluctuations in stock prices along time could distort results. Thus, forecast errors are deflated by the absolute value of forecasted earning.

Equation (1) does not try to explain what determines the forecast error in general. We are only interest in the effect of the equity issue in forecast errors so we use a model with company fixed effects. The introduction of the individual effects $\eta_{i}$ in the regression let us to control for individual characteristics which affect forecast errors.

We introduce temporal dummy variables to analyse the evolution of forecast errors around the offering. Concretely, $Y O_{i, t}$ equals one for the year of the offering and $Y 1_{i, t}, Y 2_{i, t}$ $Y 3_{i, t}$ take value one for the year one, two and three after the issue, respectively. Moreover, to compare errors between issuers and non-issuers we define the dummy variables $I_{i, t}$ and $N I_{i, t}$ which equal one for issuers and non-issuers, respectively.

Table 5 shows the estimates of regression (1). We observe that forecast errors for issuing companies are significant more negative the years following the equity issue, consistent with the argument that in the years after the offering the excessive good expectations about issuing firms' earnings are not confirmed. The evolution of forecast errors for non-issuers companies does not present any pattern. We test the equality of temporal dummies coefficients between issuing and non-issuing firms, observing that issuing firms' coefficients are statistically more negative for the three years following the issue. This result 
confirms the higher optimistic bias in analysts' predictions for companies that issue equity.

Controlling for company fixed effects, however, does not control for the striking differences observed in the forecast accuracy of analysts for profits versus losses. Concretely, as we comment in the previous section, the optimistic bias in forecast errors is higher when the actual earning is negative. In this sense, the more negative issuing firms' forecast errors for the years following the offering could be in part due to firms with losses after the equity issue.

We add the dummy explanatory variable $\operatorname{LOSS}_{i, t}$ in the regression to control for this effect. This variable takes value one if the actual earning of company $i$ in period $t$ is negative.

$$
\begin{aligned}
& F E_{i, t}=\eta_{i}+\beta_{0 I} \operatorname{LOSS}_{i, t} \times I_{i, t}+\beta_{1 I} Y 0_{i, t} \times I_{i, t}+\beta_{2 I} Y 1_{i, t} \times I_{i, t}+\beta_{3 I} Y 2_{i, t} \times I_{i, t}+\beta_{4 I} Y 3_{i, t} \times I_{i, t}+ \\
& \beta_{0 N I} \operatorname{LOSS}_{i, t} \times N I_{i, t}+\beta_{1 N I} Y 0_{i, t} \times N I_{i, t}+\beta_{2 N I} Y 1_{i, t} \times N I_{i, t}+\beta_{3 N I} Y 2_{i, t} \times N I_{i, t}+\beta_{4 N I} Y 3_{i, t} \times N I_{i, t}+\varepsilon_{i, t}
\end{aligned}
$$

Results of regression (2) illustrate that the estimate coefficients $\left(\beta_{0 I}, \beta_{0 N I}\right)$ of the $L O S S_{i, t}$ dummy are negative and highly significant. Thus, predictions errors are more negative for companies with losses both for issuers and non-issuers. This result confirms that the optimistic bias in forecast error is higher when the actual earning is negative. However, even after controlling for the higher optimistic bias of companies with losses, forecast errors for issuing companies the years following the offering are significant more negative. So we can conclude that the overoptimistic bias in issuing firms' predictions after the offering is not exclusively due to firms with negative earnings.

The coefficients of temporal dummies for non-issuers are not significant, denoting that there is not a pattern in forecast errors for non issuing firms. We also test for regression (2) the equality of temporal dummies coefficients between issuing and non-issuing companies. We observe that issuing firms' coefficients are statistically more negative for the three years following the issue, confirming that forecast errors for post-issue issuing firms' earnings present higher optimistic bias. 
TABLE 5. CROSS-SECTIONAL TIME-SERIES REGRESSIONS OF FORECAST ERRORS WITH COMPANY FIXED EFFECTS ${ }^{1}$

\begin{tabular}{|c|c|c|c|c|c|c|}
\hline & & Model (1) & & & Model (2) & \\
\hline Variable & Coefficient & t-Statistic & p-value & Coefficient & t-Statistic & p-value \\
\hline$Y 0_{i, t} \times I_{i, t}$ & -0.31 & -0.74 & 0.46 & 0.03 & 0.10 & 0.92 \\
\hline$Y 1_{i . t} \times I_{i, t}$ & -0.93 & -2.20 & 0.03 & -0.59 & -1.68 & 0.09 \\
\hline$Y 2_{i, t} \times I_{i, t}$ & -1.03 & -2.47 & 0.01 & -0.59 & -1.99 & 0.05 \\
\hline$Y 3_{i, t} \times I_{i, t}$ & -2.44 & -5.80 & 0.00 & -1.75 & -3.52 & 0.00 \\
\hline$Y 0_{i, t} \times N I_{i, t}$ & 0.14 & 0.35 & 0.72 & 0.09 & 0.35 & 0.72 \\
\hline$Y 1_{i, t} \times N I_{i, t}$ & 0.45 & 1.07 & 0.29 & 0.18 & 0.94 & 0.35 \\
\hline$Y 2_{i, t} \times N I_{i, t}$ & 0.40 & 0.94 & 0.35 & 0.18 & 0.94 & 0.35 \\
\hline$Y 3_{i, t} \times N I_{i, t}$ & 0.31 & 0.70 & 0.48 & 0.10 & 0.53 & 0.59 \\
\hline $\operatorname{LOSS}_{i, t} \times I_{i, t}$ & & & & -2.98 & -3.14 & 0.00 \\
\hline $\operatorname{LOSS}_{i, t} \times N I_{i, t}$ & & & & -1.87 & -3.30 & 0.00 \\
\hline \multicolumn{7}{|c|}{ Wald Coefficient Tests } \\
\hline Null Hypothesis & F.stat. & Probability & & F.stat. & Probability & \\
\hline$\beta_{1 I}=\beta_{1 N I}$ & 0.60 & 0.44 & & 0.02 & 0.88 & \\
\hline$\beta_{2 I}=\beta_{2 N I}$ & 5.35 & 0.02 & & 3.72 & 0.05 & \\
\hline$\beta_{3 I}=\beta_{3 N I}$ & 5.77 & 0.02 & & 4.75 & 0.03 & \\
\hline$\beta_{4 I}=\beta_{4 N I}$ & 20.1 & 0.00 & & 12.16 & 0.00 & \\
\hline$\beta_{0 I}=\beta_{0 N I}$ & & & & 1.01 & 0.32 & \\
\hline
\end{tabular}

\subsection{Long-run abnormal returns and forecasting errors}

Results in previous epigraphs show that analysts are overly optimistic about issuing firms' future earnings. Now we want to analyse if this excessive optimism explains the negative long-run abnormal returns of issuing firms the years following the offering. In order to study the relation between the prediction errors and the issuing firms' long-run returns we compute the following regression:

$$
A \operatorname{CoR}_{i, \tau}=\alpha+\beta F E_{i, \tau}+\varepsilon
$$


where $A C o R_{i, \tau}$ is the abnormal compound return of firm $i$ in the analysis period $\tau$ calculated as the compound return of the issuing firm $i$ minus the compound return of a size portfolio. We consider as analysis periods the year, two years and three years following the offering. $F E_{i, \tau}$ is the error, for company $i$, made by analysts for a forecast window of $\tau$.

Panel A of table 6 reports the results of the regression when the analysis period to calculate abnormal returns, $\tau$, is the year following the issue. To compute forecast errors we consider one-year predictions about issuing firms' earnings made by analysts the year of the offering and the following one. The coefficient $\beta$ in the regression is significantly positive for every selected date, either if errors are deflated by price or by forecasted earning. Moreover, we have computed the Spearman correlation coefficient between abnormal returns and forecast errors, being the sign of this coefficient significantly positive. So from these results we can conclude that higher the optimistic bias (more negative forecast errors) lower the longrun returns.

Panel B of table 6 shows results when $\tau$ is the two-year period following the offering. In this case, we consider two-year predictions made by analysts the issue year and the following one. Panel $\mathrm{C}$ reports results when the analysis period is the three-year period following the offering and we use three-year predictions made by analysts the year of the offering and the following one. In both panels, the $\beta$ coefficient in the regression as wells as the Spearman correlation coefficient between abnormal returns and forecast errors present a significant positive sign, either if errors are deflated by price or by forecasted earning.

Results in this epigraph are consistent with the argument of the excessive optimism about future issuing firms' earnings as the explanation of the poor long-run underperformance of these companies ${ }^{12}$.

\footnotetext{
${ }^{12}$ Similar results are obtained when abnormal returns are computed using to estimate expected returns BTM portfolios or Size-BTM portfolios.
} 
TABLE 6. RELATION BETWEEN FORECAST ERRORS AND ISSUING FIRMS ABNORMAL RETURNS

\begin{tabular}{|c|c|c|c|c|c|c|}
\hline \multirow[b]{2}{*}{ Prediction date } & \multicolumn{3}{|c|}{ Price Deflated Error } & \multicolumn{3}{|c|}{ Forecast Deflated Error } \\
\hline & month pre. & month post. & year +1 & month pre. & month post. & year +1 \\
\hline \multicolumn{7}{|c|}{ Panel A. One-Year Predictions } \\
\hline \# of firms & 34 & 34 & 33 & 34 & 34 & 33 \\
\hline$\beta$ & 0.38 & 0.39 & 0.42 & 0.45 & 0.38 & 0.36 \\
\hline t est. & $2.31 * *$ & $2.36^{* *}$ & $2.55^{* *}$ & $2.85 * * *$ & $2.22 * *$ & $2.08 * *$ \\
\hline Spearman corr. & $0.41 * *$ & $0.42 * *$ & $0.45 * * *$ & $0.35^{* *}$ & $0.38 * *$ & $0.38 * *$ \\
\hline \multicolumn{7}{|c|}{ Panel B. Two-Year Predictions } \\
\hline \# of firms & 33 & 33 & 35 & 33 & 33 & 35 \\
\hline$\beta$ & 0.36 & 0.34 & 0.50 & 0.32 & 0.34 & 0.46 \\
\hline t est. & $2.18 * *$ & $2.06 * *$ & $3.29 * * *$ & $1.87 *$ & $2.07 * *$ & $2.91 * * *$ \\
\hline Spearman corr. & $0.45^{* * *}$ & $0.38 * *$ & $0.49 * * *$ & $0.55^{* * *}$ & $0.45^{* * *}$ & $0.53 * * *$ \\
\hline \multicolumn{7}{|c|}{ Panel C. Three-Year Predictions } \\
\hline \# of firms & 34 & 34 & 30 & 34 & 34 & 30 \\
\hline$\beta$ & 0.33 & 0.41 & 0.44 & 0.35 & 0.35 & 0.37 \\
\hline t est. & $2.02 *$ & $2.61 * *$ & $2.69 * *$ & $2.12 * *$ & $2.09 * *$ & $2.17 * *$ \\
\hline Spearman corr. & $0.47 * * *$ & $0.47 * * *$ & $0.54 * * *$ & $0.54 * * *$ & $0.56 * * *$ & $0.60 * * *$ \\
\hline
\end{tabular}

$*, * *$ and $* * *$ denote statistical significance at $10 \%, 5 \%$ and $1 \%$, respectively.

\section{Market reaction to post-issue earnings announcements}

An additional test of the optimistic expectations hypothesis involves an examination of abnormal stocks returns at earnings announcements subsequent to the issue. If investors have optimistic expectations regarding future earnings they will be unpleasantly surprised at the time of earnings announcements in the post-issue period. We analyse the market reaction to the four subsequent annual earning announcements, employing standard event-study methodology.

The valuation effect to each earning announcements is evaluated from the analysis of daily abnormal returns around the event day. In particular, we study abnormal returns in the 
window $(-5,+5)$, where the day 0 is the $k$ th earning announcement following the offering $(k=1 \ldots 4)$. Abnormal returns are calculated employing the market model to estimate expected returns,

$$
A R_{i, t}=R_{i, t}-\left(a_{i}+b_{i} R_{M, t}\right)
$$

where $A R_{i, t}$ and $R_{i, t}$ are the abnormal return and the real return of firm $i$ in day $t$, respectively, $R_{M, t}$ is the market portfolio return in day $t$, and $a_{i}, b_{i}$ are the ordinary least squared estimated coefficients of the market model. The estimation period for the market model comes from the day $t=-150$ through $t=-6$, where $t=0$ is the $k$ th earning announcement following the offering.

To test if daily abnormal returns are statistically different form zero we employ the parametric test of Boehmer et al. (1991) that takes into account the change in variance of returns induced by the event and the cross-section heterocedasticity of prediction errors. We complete the analysis of daily abnormal returns around the earning announcements with the non-parametric test of Corrado (1989).

Additionally, the market response to post-issue earning announcements can also be measured examining cumulative abnormal returns in different windows within the event period. In particular, cumulative abnormal return in the window $\left(t_{1}, t_{2}\right)$ is computed as $\operatorname{CAR}\left(t_{1}, t_{2}\right)=\sum_{t=t_{1}}^{t_{2}} A R_{i, t}$

Table 7 reports the results of the market reaction to the four post-issue annual earning announcements. When we analyse the effect of the first announcement following the offering, we observe that the mean cross-sectional abnormal return is negative from day -1 to day +3 , being statistically significant in the announcement day both with the Boehmer et al. test and with the Corrado test. We also examine cumulative abnormal returns in three windows within the event period. We observe that cumulative abnormal returns around the announcement day are also significantly negative with both tests. 
TABLE 7. MARKET REACTION TO POST-ISSUE EARNINGS ANNOUNCEMENTS

\begin{tabular}{|c|c|c|c|c|c|c|c|c|c|c|c|c|}
\hline \multirow[b]{2}{*}{ day } & \multicolumn{3}{|c|}{$\begin{array}{c}1^{\text {st }} \text { post-issue earning } \\
\text { announcement } \\
(\mathrm{N}=25)\end{array}$} & \multicolumn{3}{|c|}{$\begin{array}{c}2^{\text {nd }} \text { post-issue earning } \\
\text { announcement } \\
(\mathrm{N}=34) \\
\end{array}$} & \multicolumn{3}{|c|}{$\begin{array}{c}3^{\text {rd }} \text { post-issue earning } \\
\text { announcement } \\
(\mathrm{N}=40)\end{array}$} & \multicolumn{3}{|c|}{$\begin{array}{c}4^{\text {th }} \text { post-issue earning } \\
\text { announcement } \\
(\mathrm{N}=40) \\
\end{array}$} \\
\hline & $\bar{A} R_{t}(\%)$ & Boehmer & Corrado & $\bar{A} R_{t}(\%)$ & Boehmer & Corrado & $\bar{A} R_{t}(\%)$ & Boehmer & Corrado & $\bar{A} R_{t}(\%)$ & Boehmer & Corrado \\
\hline-5 & 0.44 & 0.95 & 1.03 & 0.31 & 0.39 & -0.27 & 0.04 & 0.98 & 1.54 & -0.26 & -0.64 & -0.18 \\
\hline-4 & 0.32 & 0.44 & 1.33 & 0.40 & 1.11 & 0.38 & -0.02 & -0.48 & 0.53 & -0.09 & -0.16 & 0.24 \\
\hline-3 & -0.13 & -0.80 & -0.29 & 0.24 & 0.19 & 1.25 & 0.15 & 0.91 & 0.76 & 0.13 & 0.77 & -0.06 \\
\hline-2 & 0.01 & 0.50 & 0.81 & 0.07 & 1.11 & 0.56 & 0.23 & 0.77 & 0.36 & 0.00 & 0.32 & -0.02 \\
\hline-1 & -0.23 & -1.10 & -1.02 & -0.21 & -0.23 & 0.49 & -0.58 & $-2.31 * *$ & -1.35 & -0.45 & -1.47 & $-2.56 * * *$ \\
\hline 0 & -1.12 & $-2.30 * *$ & $-2.48 * *$ & -0.75 & $-2.24 * *$ & -1.91 & -0.60 & -1.68 & -1.51 & -0.71 & $-3.18 * * *$ & $-2.62 * * *$ \\
\hline+1 & -0.57 & $-1.80^{*}$ & -1.53 & -0.29 & -0.89 & -0.57 & -0.38 & -1.53 & -1.92 & -0.37 & -0.94 & -0.87 \\
\hline+2 & -0.46 & -1.10 & -1.23 & -0.02 & -0.54 & -0.48 & -0.36 & -0.93 & -0.56 & -0.14 & -0.36 & 0.42 \\
\hline+3 & -0.10 & -0.30 & -0.05 & 0.02 & -0.23 & 0.36 & -0.27 & -1.24 & -1.29 & 0.30 & 0.90 & 1.24 \\
\hline+4 & 0.20 & 0.75 & 1.45 & 0.31 & 0.84 & 0.67 & 0.14 & 0.41 & 0.89 & 0.21 & 1.21 & 0.88 \\
\hline+5 & 0.26 & 0.43 & 0.14 & 0.56 & 1.62 & 1.40 & 0.18 & 0.92 & 1.18 & -0.01 & -0.45 & -0.39 \\
\hline$(-1,1)$ & -1.92 & $-2.71 * *$ & $-2.91 * * *$ & -1.25 & $-1.92 *$ & -1.15 & -1.56 & $-3.25 * * *$ & $-2.76 * * *$ & -1.54 & $-3.13 * * *$ & $-3.49 * * *$ \\
\hline$(-1,0)$ & -1.69 & $-2.98 * * *$ & $-2.84 * * *$ & -1.04 & $-2.76^{* * *}$ & $-1.75^{*}$ & -0.98 & $-2.29 * * *$ & $-2.43 * * *$ & -1.08 & $-2.75 * * *$ & $-2.47 * * *$ \\
\hline$(0,1)$ & -1.35 & $-3.10 * * *$ & $-2.48 * *$ & -0.96 & -1.49 & -1.00 & -1.18 & $-3.16^{* * *}$ & $-2.02 * *$ & -1.16 & $-3.34 * * *$ & $-3.67 * * *$ \\
\hline
\end{tabular}

$*, * *, * * *$ denote statistical significance at $10 \%, 5 \%$ and $1 \%$ level, respectively. 
Results for the second, third and fourth post-issue earning announcement also show a negative market reaction. For every announcement we observe that abnormal returns are negative the days around it, being statistically significant the day of the announcement for the second a fourth earning announcement. However, for the third post-issue earning announcement the negative market reaction is significant for the day before the announcement. This result can be due to leaked information before the announcement or to an inaccurate earning announcement date.

Cumulative abnormal returns around the second, third and fourth post-issue announcements are also significantly negative corroborating that the market is unpleasantly surprised within earnings announcement windows following equity rights issues. These results are also consistent with the market being overly optimistic about the long-term prospects of issuing firms at the time of the offering.

\section{Conclusions}

In this paper we document that equity rights issuers underperform in the longrun and we test if the origin of this pattern is the excessive optimism about issuing firms' prospects. For that, firstly, we examine analysts' predictions about future earnings of these companies. Our results show that both short and long-term earning forecasts for rights issuing firms are unusually favourable in relation to predictions for non-issuers. Moreover, we find a significant relation between the optimism in forecast errors and long-run returns of rights issuers; in particular, higher the optimistic bias in analysts' predictions lower the long-run returns. These results suggest that the explanation of the poor long-run rights issuing firms' underperformance is the excessive optimism about future earnings of these companies.

Secondly, we examine the market reaction to the fourth post-issue annual earning announcements as additional test of the optimistic expectations hypothesis. We observe that the market is unpleasantly surprised at the time of earning announcements in the post-issue period. This finding reinforces our conclusion of the market being overly optimistic regarding future earnings and being disappointed by the lower earnings realized by firms following seasoned equity offerings. 
Overall, our results lead to the conclusion that the rights issuers' underperformance is due, at least in part, to investors having overestimated the future earnings potential of these companies. 


\section{APPENDIX. CORRELATION BETWEEN FORECAST ERRORS AND ACTUAL OR FORECASTED EARNING TO PRICE RATIOS ${ }^{1}$}

\begin{tabular}{llccc} 
Panel A. One-Year Predictions & \multicolumn{1}{l}{} \\
\hline & $\mathbf{1}$ & $\mathbf{2}$ & $\mathbf{3}$ & $\mathbf{4}$ \\
\hline 1. Error deflated by stock price & -- & $0.922^{* * *}$ & $0.224^{* * *}$ & $0.349^{* * *}$ \\
2. Error deflated by forecasted earning & & -- & 0.023 & -0.03 \\
3. Actual Earning to Price ratio & & & -- & $0.713^{* * *}$ \\
4. Forecasted Earning to price ratio & & & & --
\end{tabular}

Panel B. Two-Year Predictions

\begin{tabular}{|c|c|c|c|c|}
\hline & 1 & 2 & 3 & 4 \\
\hline 1. Error deflated by stock price & -- & $0.906 * * *$ & $0.176^{* * *}$ & $0.266 * * *$ \\
\hline 2. Error deflated by forecasted earning & & -- & -0.048 & -0.093 \\
\hline 3. Actual Earning to Price ratio & & & -- & $0.445 * * *$ \\
\hline 4. Forecasted Earning to price ratio & & & & -- \\
\hline \multicolumn{5}{|l|}{ Panel C. Three-Year Predictions } \\
\hline & 1 & 2 & 3 & 4 \\
\hline 1. Error deflated by stock price & -- & $0.918 * * *$ & $0.157 * * *$ & $0.254 * * *$ \\
\hline 2. Error deflated by forecasted earning & & -- & -0.067 & -0.083 \\
\hline 3. Actual Earning to Price ratio & & & -- & $0.405 * * *$ \\
\hline 4. Forecasted Earning to price ratio & & & & -- \\
\hline
\end{tabular}

${ }^{1}$ We consider appropriate Spearman correlation coefficient due to non-normality distribution of forecast errors. We compute, for every firm in IBES database, two and three- year forecast errors in December of each year in the sample period.

*** denotes significance at $1 \%$ level. 


\section{References}

Ali, A. (1996). Bias in Analyst Earning Forecast as an Explanation for the Long-Run Underperformance of Stocks Following Equity Offerings. Working paper, University of Arizona.

Barber, B.M. and Lyon, J.D. (1997). Detecting Long-Run Abnormal Stock Returns: the Empirical Power and Specification of Tests Statistics. Journal of Financial Economics, $43,341-472$.

Boehmer, E., Musumeci, J. and Poulsen, A. (1991). Event-Study Methodology under Conditions of Event-Induced Variance, Journal of Financial Economics, 30, 253-272.

Brous, P.A., Datar, V. and Kini, O. (2001). Is the Market Optimistic about the Future Earnings of Seasoned Equity Offering Firms? Journal of Financial and Quantitative Analysis, 36, 141-168.

Brown, L.D. and Rozeff, M.S. (1978). The Superiority of Analyst Forecasts as Measures of Evidence from Earnings, Journal of Finance, 33, 1-16.

Brown, L.D. (1996). Forecasting Errors and Their Implications for Security Analysis: An Alternative Perspective. Financial Analysts Journal, 52, 40-47.

Brown, L.D. (1997). Analyst Forecasting Errors: Additional Evidence. Financial Analysts Journal, 53, 81-88.

Brown, P., Foster, G. and Noreen, E. (1985). Security analysts multi-year earnings forecasts and the capital market. Studies in Accounting Research 21.

Bulter, K.C. and Saraoglu, H. (1999). Improving Analysts' Negative Earnings Forecasts. Financial Analysts Journal, 55, 48-56.

Cai, J. (1998). The Long-Run Performance Following Japanese Rights Issues. Applied Financial Economics, 8, 419-434.

Clayman, M.R. and Schwartz, R.A. (1994). Falling in Love Again-Analysts' Estimates and Reality. Financial Analysts Journal, 50, 66-68.

Cornett, M.M.; Mehran, H. and Tehranian, H. (1998). Are Financial Markets Overly Optimistic about the Prospects of Firms that Issue Equity? Evidence from Voluntary versus Involuntary Equity Issuances by Banks. The Journal of Finance, 53, 2139-2159.

Corrado, C. (1989). A Non-parametric Test for Abnormal Security- Price Performance in Event Studies. Journal of Financial Economics, 23, 385-395.

Dechow, P.; Hutton, A. and Sloan, R. (2000). The relation between Analysts' Forecasts of Long-Term Earnings Growth and Stock Price Performance Following Equity Offerings. Contemporary Accounting Research, 17, 1-32. 
Denis, D.J. and Sarin, A. (2001). Is the Market Surprised by Poor Earnings Realizations following Seasoned Equity Offerings? Journal of Financial and Quantitative Analysis, 36, 169-193.

Doukas, J.A.; Kim, C. and Pantzalis, C. (2001). A Test of Errors-in-Expectations Explanation of the Value/Glamour Stock Returns Performance: Evidence from Analysts' Forecasts. Journal of Finance, 57, 2143-2165.

Dowen, R.J. (1996). Analyst Reaction to Negative Earnings for Large Well-Known Firms. The Journal of Portfolio Management, 23, 49-55.

Dreman, D.N. and Berry, M.A. (1995). Analyst Forecasting Errors and their Implications for Security Analysis. Financial Analysts Journal, 51, 30-41.

Elton, E.L.; Gruber, M.J. and Gultekin, M.N. (1984). Professional Expectations: Accuracy and Diagnosis of Errors, Journal of Financial and Quantitative Analysis, 18, 351-363.

Hansen, R. and Sarin, A. (1998). Are Analysts overoptimistic around seasoned equity offerings? Working paper, Santa Clara University.

Jeanneret, P. (2000). Use of the Proceeds and Long-Term Performance of French SEO Firms, European Financial Management Association Congress (EFMA), Athens.

Jegadeesh, N. (2000). Long-Term Performance of Seasoned Equity Offerings: Benchmark Errors and Biases in Expectations, Financial Management, 29, 5-30.

Johnson, N.J. (1978). Modified t tests and confidence intervals for asymmetrical populations, Journal of the American Statistical Association, 73, 536-544.

Kang, J.K.; Kim Y.C. and Stulz R. M. (1999). The Underreaction Hypothesis and the New Issue Puzzle: Evidence From Japan. The Review of Financial Studies, 12, 519-534.

Kothari, S.P. and Warner, J.B. (1997). Measuring Long-Horizon Security Price Performance. Journal of Financial Economics, 43, 301-339.

Larrán, M. and Rees, W. (1999). Propiedades de los pronósticos de beneficios realizados por los analistas financieros: una aplicación al caso español. Revista Española de Financiación $y$ Contabilidad, 28, 675-729.

Lee, I. (1997). Do Firms Knowingly Sell Overvalued Equity? Journal of Finance, 52, 14391466.

Lin, H. and McNichols, M. (1998). Underwriting Relationships and Analysts' Earnings Forecasts and Investment Recommendations, Journal of Accounting and Economics, $25,101-127$.

Loughran, T. and Ritter, J. R. (1995). The New Issues Puzzle. Journal of Finance, 50, 23-51. 
Loughran, T. and Ritter, J.R. (1997). The Operating Performance of Firms Conducting Seasoned Equity Offerings. Journal of Finance, 52, 1823-1850.

Lyon J.D.; Barber, B.M. and Tsai C. (1999). Improved Methods for Tests of Long-Run Abnormal Stock Returns. Journal of Finance, 54, 165-201.

Marciukaityte, D. and Szewczyk, S.H. (2001). Market Efficiency and Seasoned Equity Offerings. Presented in the Financial Management Association Annual Meeting.

McLaughlin, R.; Safieddine, A. and Vasudevan, G.K. (1996). The Operating Performance of Seasoned Equity Issuers: Free Cash Flow and Post-Issue Performance. Financial Management, 25, 41-53.

McNichols, M. and O'Brien, P.C. (1997). Self-selection and analyst coverage. Journal of Accounting Research 35, 167-199.

Mian, G.M. and Teo, T.G. (2001). Do errors in expectations explain the cross-section of stock returns? Working paper, National University of Singapore.

O'Brien, P.C. (1988). Analysts' Forecasts as Earnings Expectations. Journal of Accounting and Economics, 10, 53-83.

Pastor, M.J. and Martín, J.F. (2001). Efectos a largo plazo de las ampliaciones de capital en el mercado español. Instituto Valenciano de Investigaciones Económicas, WP-EC 200126.

Pastor, M.J. and Martín J.F. (2004). Long-run Performance of Spanish Seasoned Equity Issues with Rights. International Review of Financial Analysis, forthcoming.

Rajan, R. and Servaes, H. (1997). Analyst Following of Initial Public Offerings. The Journal of Finance, 52, 507-529.

Rangan, S. (1998). Earning Management and the Performance of Seasoned Equity Offerings. Journal of Financial Economics, 50, 101-122.

Richardson, S.; Teoh, S.H. and Wysocki, P. (2000). The Walkdown to Beatable Analyst Forecasts: The Roles of Equity Issuance and Insider Trading Incentives. Working paper, University of Michigan.

Shivakumar, L. (2000). Do Firms Mislead Investors by Overstating Earnings before Seasoned Equity Offerings? Journal of Accounting and Economics, 29, 339-371.

Spiess, D.K. and Affleck-Graves, J. (1995). Underperformance in Long-Run Stock Returns Following Seasoned Equity Offerings. Journal of Financial Economics, 38, 243-267.

Stehle, R.; Ehrhardt, O. and Przyborowsky, R. (2000). Long-Run Stock of German Initial Public Offerings and Seasoned Equity Issues. European Financial Management, 6, 173-196. 
Teoh, S.W. and Wong, T.J. (2002). Why New Issues and High-Accrual firms Underperform: The Role of Analysts' Credulity. Review of Financial Studies, 15, 869-900. 